\title{
Effect of Transient Nicotine Load Shock on the Performance of Pseudomonas sp. HF-1 Bioaugmented Sequencing Batch Reactors
}

\author{
Dong-sheng Shen, ${ }^{1,2}$ Li-jia Wang, Hong-zhen He, ${ }^{1}$ and Mei-zhen Wang ${ }^{1,2}$ \\ ${ }^{1}$ School of Environmental Science and Engineering, Zhejiang Gongshang University, Hangzhou 310012, China \\ ${ }^{2}$ Zhejiang Provincial Key Laboratory of Solid Waste Treatment and Recycling, Hangzhou 310012, China
}

Correspondence should be addressed to Mei-zhen Wang; wmz@zjgsu.edu.cn

Received 22 December 2015; Revised 20 May 2016; Accepted 24 May 2016

Academic Editor: Wenshan Guo

Copyright (C) 2016 Dong-sheng Shen et al. This is an open access article distributed under the Creative Commons Attribution License, which permits unrestricted use, distribution, and reproduction in any medium, provided the original work is properly cited.

\begin{abstract}
Bioaugmentation with degrading bacteria can improve the treatment of nicotine-containing tobacco industrial wastewater effectively. However, the transient and extremely high feeding of pollutants may compromise the effectiveness of the bioaugmented reactors. The effect of transient nicotine shock loads on the performance of Pseudomonas sp. HF-1 bioaugmented SBRs were studied. The results showed that, under $500-2500 \mathrm{mg} / \mathrm{L}$ of transient nicotine shocks, all the reactors still could realize $100 \%$ of nicotine degradation in 4 days of recovery, while the key nicotine degradation enzyme HSP hydroxylase increased in expression. Though the dramatic increase of activities of ROS, MDA, SOD, and CAT suggested that transient nicotine shock loads could induce oxidative stress on microorganisms in activated sludge, a decrease to control level demonstrated that most of the microorganisms could resist $500-1500 \mathrm{mg} / \mathrm{L}$ of transient nicotine shock under the protection from strain HF-1. After 8 cycles of recovery, high ROS level and low TOC removal in high transient shock reactors implied that $2000-2500 \mathrm{mg} / \mathrm{L}$ of transient nicotine shock was out of its recovery of strain HF-1 bioaugmented system. This study enriched our understanding on highly efficient nicotine-degrading strain bioaugmented system, which would be beneficial to tobacco waste or wastewater treatment in engineering.
\end{abstract}

\section{Introduction}

Nicotine is the main addictive component in tobacco and is the primary toxic compound in tobacco waste [1]. In fact, more than 60 tons of tobacco wastewater is discharged to produce only 1 ton of cigarettes [2]. Approximately, more than 500 billion tons of nicotine-containing wastewater is discharged globally each year [3]. As is known to all, nicotine can easily permeate different kinds of cell membrane even the blood-brain barrier [4], which is carcinogenic, teratogenic, and mutagenic [5]. Nicotine-containing tobacco wastewater treatment has attracted widespread attention.

With the isolation of highly efficient nicotine-degrading microorganisms, bioaugmentation has been well-developed [6-9]. In our previous study, we used Pseudomonas sp. HF1 and Acinetobacter sp. TW to colonize in activated sludge for bioaugmentation, respectively. Both of these systems were operated excellently, with nearly $100 \%$ of nicotine degradation and more than $80 \%$ of chemical oxygen demand (COD) removal $[1,10]$. Compared to the traditional activated sludge technology, bioaugmentation with highly efficient degrading bacteria is a powerful way to treat nicotinecontaining tobacco wastewater.

For better development of bioaugmentation in nicotinecontaining tobacco wastewater treatment, we did considerable amount of analysis both on traditional and on bioaugmented activated sludge systems. Actually, higher than $250 \mathrm{mg} / \mathrm{L}$ of nicotine can induce oxidative stress and inhibit bacterial activities when there were no nicotinedegrading bacteria in the activated sludge [11]. However, in the bioaugmented system, nicotine was rapidly degraded by highly efficient nicotine-degrading bacteria and the toxicity from nicotine on the bacterial community was minimized [1]. Highly efficient degrading strain played an important role in their good performance of bioaugmented systems $[12,13]$. 
As the main toxicant in tobacco wastewater, nicotine takes a dominant part in inducing oxidative stress. With the increasing of nicotine concentration in wastewater, the content of reactive oxygen species (ROS) increased accordingly [14]. After bioaugmentation and acclimation, ROS was maintained in the reasonable range and the system was stably operated $[10,11]$. Notably, stable operation is an ideal laboratory model. In the engineering operation, bioaugmented systems have to confront the nicotine load shock. Because of the changes of raw materials and production process in the cigarette manufacture, it could be up to $1000 \mathrm{mg} / \mathrm{L}$ of nicotine, which is 4 times the normal feed on our Pseudomonas sp. HF1 bioaugmented system. Though a lot of studies investigated the performance of bioaugmented system in stable pollutant load, few studies give us the information about the operation under the shock of pollutant load. Shock tolerance is very important in the application of bioaugmented system in engineering.

In this study, reactor performance was investigated under different nicotine load shock. Besides, community structure and activities of nicotine-degrading strain were traced. In addition, oxidative stress was monitored by measuring four popular biomarkers ROS, malondialdehyde (MDA), catalase (CAT), and superoxide dismutase (SOD). This systematic report will give us the insight about how bioaugmented system confronts nicotine shock. It also will give us more information for future application of this technology in the tobacco wastewater treatment.

\section{Materials and Methods}

2.1. Experimental Set-Up. Experiments were conducted in six identical sequencing batch reactors (SBRs) named R1, $\mathrm{R} 2, \mathrm{R} 3, \mathrm{R} 4, \mathrm{R} 5$, and R6, with $1 \mathrm{~L}$ of working volume. All the reactors were maintained at room temperature $(28 \pm$ $\left.2^{\circ} \mathrm{C}\right)$ throughout the whole period of this experiment. An air pump through diffuser was employed to maintain $3-5 \mathrm{mg} / \mathrm{L}$ of dissolved oxygen (DO). Activated sludge with strain HF-1 colonization was inoculated into each reactor with a biomass of $3.9 \pm 0.06 \mathrm{~g} \mathrm{SS} / \mathrm{L}$. The reactors were operated on a $24 \mathrm{~h}$ cycle, and each cycle included $5 \mathrm{~min}$ influent filling, $10 \mathrm{~min}$ effluent withdrawal, $30 \mathrm{~min}$ settling and aeration for the rest of the time. After settling, effluent was discharged at $50 \%$ of volumetric exchange ratio.

Activated sludge with strain HF-1 colonization was cultured as follows: the activated sludge from Qige wastewater treatment plant (Hangzhou, Zhejiang, China) was used as the endogenous seed. Strain HF-1 was inoculated into the seed activated sludge. After stopping inoculating for 7 days, reverse-transcription-PCR was amplified to detect the colonization of strain HF-1 [15]. Once the colonization of strain HF-1 in activated sludge was successful, the activated sludge was used as the inoculating activated sludge for the set-up of the above-mentioned six identical reactors.

The tobacco wastewater to feed all reactors was prepared as follows: nicotine- containing tobacco waste collected from China Tobacco Zhejiang Industrial Co. Ltd. was mixed with distilled water. Then, the mixture was filtered and diluted for the SBR treatments. In the present study, the behavior of reactors was monitored under five different transient shock loads. Initially, reactors were operated with nicotine concentration of $250 \mathrm{mg} / \mathrm{L}$ at $24 \mathrm{~h}$ hydraulic retention (HRT) for 5 days to uniform the six identical reactors. To evaluate the effect from shock loads, the final concentration of nicotine in these reactors sharply reached $500 \mathrm{mg} / \mathrm{L}$ (2fold), $1000 \mathrm{mg} / \mathrm{L}$ (4-fold), $1500 \mathrm{mg} / \mathrm{L}$ (6-fold), $2000 \mathrm{mg} / \mathrm{L}$ (8fold), and $2500 \mathrm{mg} / \mathrm{L}$ (10-fold) in R2, R3, R4, R5, and R6, respectively. Reactor $\mathrm{R} 1$ feeding with $250 \mathrm{mg} / \mathrm{L}$ nicotine was used as a control.

2.2. Evaluation of Reactor Performance. Influent and effluent were sampled and analyzed for nicotine and total organic carbon (TOC) through the period of operation. Nicotine concentration was analyzed by WATERS high performance liquid chromatography (HPLC) using an X Bridge C-18 column ( $5 \mu \mathrm{m}$ i.d., $4.6 \times 250 \mathrm{~mm}$ ). The mobile phase consisted of $0.1 \%$ triethylamine and methanol $(40: 60, \mathrm{v} / \mathrm{v})$ was applied at a flow rate of $1 \mathrm{~mL} / \mathrm{min}$. And nicotine was detected at $254 \mathrm{~nm}$. The TOC concentration was determined using a TOC analyzer (Shimadzu, Japan).

\subsection{Detection of Strain HF-1 in Activated Sludge. Total RNA} from the 6 th $d$ and 14 th d activated sludge was extracted using the Bioteke soil RNA isolation kit (Bioteke, Beijing, China). Then, total RNA was treated with DNase I (RNase-free) at a concentration of $1 \mathrm{U} / \mu \mathrm{g}$ for $30 \mathrm{~min}$ at $37^{\circ} \mathrm{C}$ to remove contaminating DNA. The RNA was reversely transcribed to cDNA by using the TransGene RT-PCR kit. Quantitative real-time PCR was carried out to quantify bacteria strain HF-1 in activated sludge. The $16 \mathrm{~S}$ rRNA gene was used as a housekeeping gene, whose primer pair is $338 \mathrm{~F}\left(5^{\prime}\right.$-CCTACGGGAGGCAGCAG$\left.3^{\prime}\right)$ and 518R (5'-ATTACCGCGGCTGCTGG-3'). The specific hsp gene of strain HF-1 was amplified to quantity the amount of strain HF-1 in activated sludge, whose primer pair is $h s p \mathrm{~S}\left(5^{\prime}\right.$-ATACTGCCGACAACAACTAACC- $\left.3^{\prime}\right)$ and $h s p$ A $\left(5^{\prime}\right.$-CACTCCAGAAACGAAAAAACC- $\left.3^{\prime}\right)$. Real-time PCR was performed in a $10 \mu \mathrm{L}$ reaction mixture system containing $5 \mu \mathrm{L}$ iQ SYBR Green Supermix (Bio-Rad Laboratories Inc., Hercules, CA), $0.2 \mu \mathrm{L}$ of each primer $(10 \mu \mathrm{M}), 1 \mu \mathrm{L}$ cDNA (approximately $5 \mathrm{ng}$ ), and $3.6 \mu \mathrm{L}$ sterile $\mathrm{H}_{2} \mathrm{O}$. Realtime PCR conditions were as follows: $95^{\circ} \mathrm{C}$ for $3 \mathrm{~min}$, followed by 40 cycles of $95^{\circ} \mathrm{C}$ for $20 \mathrm{~s}, 58^{\circ} \mathrm{C}$ for $20 \mathrm{~s}$, and $72^{\circ} \mathrm{C}$ for $20 \mathrm{~s}$. At the end, melt curve analysis was performed by the addition of a final step, starting at $65^{\circ} \mathrm{C}$ and going to $95^{\circ} \mathrm{C}$; the signal was monitored every $5 \mathrm{~s}$ with a $0.5^{\circ} \mathrm{C}$ temperature increment. The relative abundance of strain HF-1 was normalized by $h s p$ gene expression against the $16 \mathrm{~S}$ rRNA through $2^{-\Delta \Delta \mathrm{Ct}}$ method [16].

2.4. Bacterial Community Analysis. PCR as well as denaturing gradient gel electrophoresis (PCR-DGGE) was used to analyze bacterial community in the reactors on 14 th $\mathrm{d}$. DNA was extracted from activated sludge samples using Bioteke sludge DNA isolation kit (Bioteke, China). PCR was performed with primers targeting bacterial 16S rRNA gene (P338F with GC-clamp and P518R). DGGE analyses were conducted with a Bio-Rad DCode system (Hercules, CA) using a $10 \%$ (wt/vol) polyacrylamide gel and a denaturing 
gradient from 40 to $60 \%$. The gels were run at $90 \mathrm{~V}$ and $60^{\circ} \mathrm{C}$ for $20 \mathrm{~min}$, followed by $160 \mathrm{~V}$ and $60^{\circ} \mathrm{C}$ for $6.5 \mathrm{~h}$. The gels were visualized by silver staining [17] and photographed using a gel imaging instrument. DGGE were analyzed using Quantity One software (version 4.6.2, Bio-Rad). A clustering analysis was performed using the unweighted pair group method with arithmetic means (UPGMA) [18].

2.5. Toxicity Assay. Activated sludge was collected on 4th d, 6th d, and 14th d by centrifugation at $12000 \mathrm{rpm}$ for $10 \mathrm{~min}$. Each sample was washed three times with phosphate buffer solution (PBS) and resuspended in $2 \mathrm{~mL}$ of PBS [13]. Then, the suspension was ultrasonically disrupted on ice for 99 cycles (with $3 \mathrm{~s}$ of working and $5 \mathrm{~s}$ of cooling between burst) by using a sonifier (Sonics, USA). Subsequently, the suspension was centrifuged at $12000 \mathrm{rpm}$ and $4^{\circ} \mathrm{C}$ for $20 \mathrm{~min}$ and the supernatant was collected for toxicity assay.

The total protein content in the supernatant was determined by a modified Bradford method [19]. The activity of ROS was analyzed using the commercial ROS ELISA Kit purchased from the Chunxiang Biotechnology Co. Ltd. (Shanghai, China). The activities of MDA, SOD, and CAT were detected using the spectrophotometric protocols with kits A003, A001, and A007 purchased from the Nanjing Jiangcheng Bioengineering Institute (Jiangsu, China).

2.6. Statistical Analysis. All data were presented as mean \pm standard error. One-way analysis of variance (ANOVA) was performed using SPSS software (version 19.0). The levels of significance were tested at $p<0.05$.

\section{Results and Discussion}

3.1. Performance of the Reactors. The experiment lasted for $14 \mathrm{~d}$. The efficiency of nicotine as well as TOC removal of all the reactors was routinely monitored (Figure 1). Before nicotine shock loads (from day 5 onwards), all reactors were efficient at pollutant removal with $100 \%$ of nicotine degradation and nearly $80 \%$ of TOC removal. There was no significant difference between all the reactors.

On the 5 th day, we performed the nicotine shock. Final nicotine concentration in R2, R3, R4, R5, and R6 was 500, $1000,1500,2000$, and $2500 \mathrm{mg} / \mathrm{L}$, respectively. In order to evaluate the effect of nicotine shock on reactor performance, nicotine degradation and TOC removal were calculated as follows: nicotine degradation $(\%)=\left([\text { nicotine }]_{\text {before cycles }}-\right.$ $\left.[\text { nicotine }]_{\text {after cycles }}\right) /[\text { nicotine }]_{\text {before cycles }} \times 100 \%$; TOC removal $(\%)=\left([\mathrm{TOC}]_{\text {before cycles }}-[\mathrm{TOC}]_{\text {after cycles }}\right) /$ $[\text { TOC }]_{\text {before cycles }} \times 100 \%$.

Though the decline of nicotine and TOC removal efficiencies in R2-R6 was observed at the beginning of nicotine shock, all of the systems could be recovered after several days of nicotine shock. As seen in Figure 1, nicotine degradation in R2, R3, R4, R5, and R6 could be totally recovered within 2, 3, 4, 4, and $4 \mathrm{~d}$ after 2-fold, 4-fold, 6-fold, 8-fold, and 10fold nicotine shock, respectively. Pseudomonas sp. HF-1 could express high nicotine tolerance even in complicated activated sludge environment.
Compared to nicotine degradation, it took a longer time to recover the TOC removal. TOC removal in R2, R3, and R4 could be recovered within 2, 3, and $4 \mathrm{~d}$ after 2 -fold, 4-fold, and 6-fold shock, respectively. However, TOC removal in R5 and R6 was hard to be recovered under 8 -fold and 10 -fold shock. After $7 \mathrm{~d}$, TOC was still lower than $70 \%$ of removal. Under 2000-2500 mg/L of nicotine shocks, native bacteria in activated sludge were possibly suffered.

3.2. Strain HF-1 in the Reactors. Quantitative real-time PCR was used to estimate the dynamic changes of the relative abundance of strain HF-1 with different concentrations of nicotine shock [10]. Gene hsp, which encodes HSP hydroxylase, is one of the key nicotine-degrading genes in strain HF-1 [20-22]. The more the copies of gene hsp are detected, the more the strain HF-1 exists in activated sludge [1]. In our preliminary study, gene hsp could not be detected in the original activated sludge obtained from Qige Treatment Plant.

As seen in Figure 2, compared with the control reactor R1, a sharp increase was noticed in all experimental groups (R2R6) after shock loads (6th d). The activity of HSP hydroxylase in R3-R6 with $1000-2500 \mathrm{mg} / \mathrm{L}$ nicotine shock loads was significantly higher than R2 with $500 \mathrm{mg} / \mathrm{L}$ nicotine shock loads. After being recovered for 8 cycles, the activity returned but was still significantly higher than R1. These results could well explain why all reactors could recover nicotine degradation within 4 days even up to $2500 \mathrm{mg} / \mathrm{L}$ of nicotine load shock. With the sharp increasing of nicotine, more strain HF-1 reproduced to degrade nicotine. After rapidly degrading nicotine, the amount of strain HF-1 decreased due to limitation of nicotine. A good fitness of strain HF-1 to nicotine could bring a bright prospect to the development of bioaugmentation in tobacco wastewater treatment.

3.3. Bacterial Community of the Reactors. The activated sludge on the 14th d was sampled from each reactor and analyzed by PCR-DGGE. As shown in Figure 3, bands in the DGGE profile were similar in their amounts and sites. This suggested that the structures of bacterial communities in different reactors were similar. The transient shock loads of nicotine from 500 to $2500 \mathrm{mg} / \mathrm{L}$ would not change the microbial species present in activated sludge greatly.

According to the clustering analysis of DGGE pattern, R5 and R6, with 8-fold and 10-fold shock, were assembled together. For the DGGE pattern analysis, the density of band was taken into account to evaluate the bacterial abundance. As mentioned before, TOC removal was hard to be recovered under 8 -fold and 10-fold shock. These might implicate that, under 8-fold and 10-fold shock, the activity of bacterial communities was suffered. Actually, when the population of microorganisms is lower than a certain abundance, it is hard to be detected by PCR-DGGE [23]. Thus, some other strategies should be developed to analyze the bacterial community within such short period.

3.4. Oxidative Stress in the Reactors. Toxic and hazardous compound is responsible for ROS produce, which is capable 

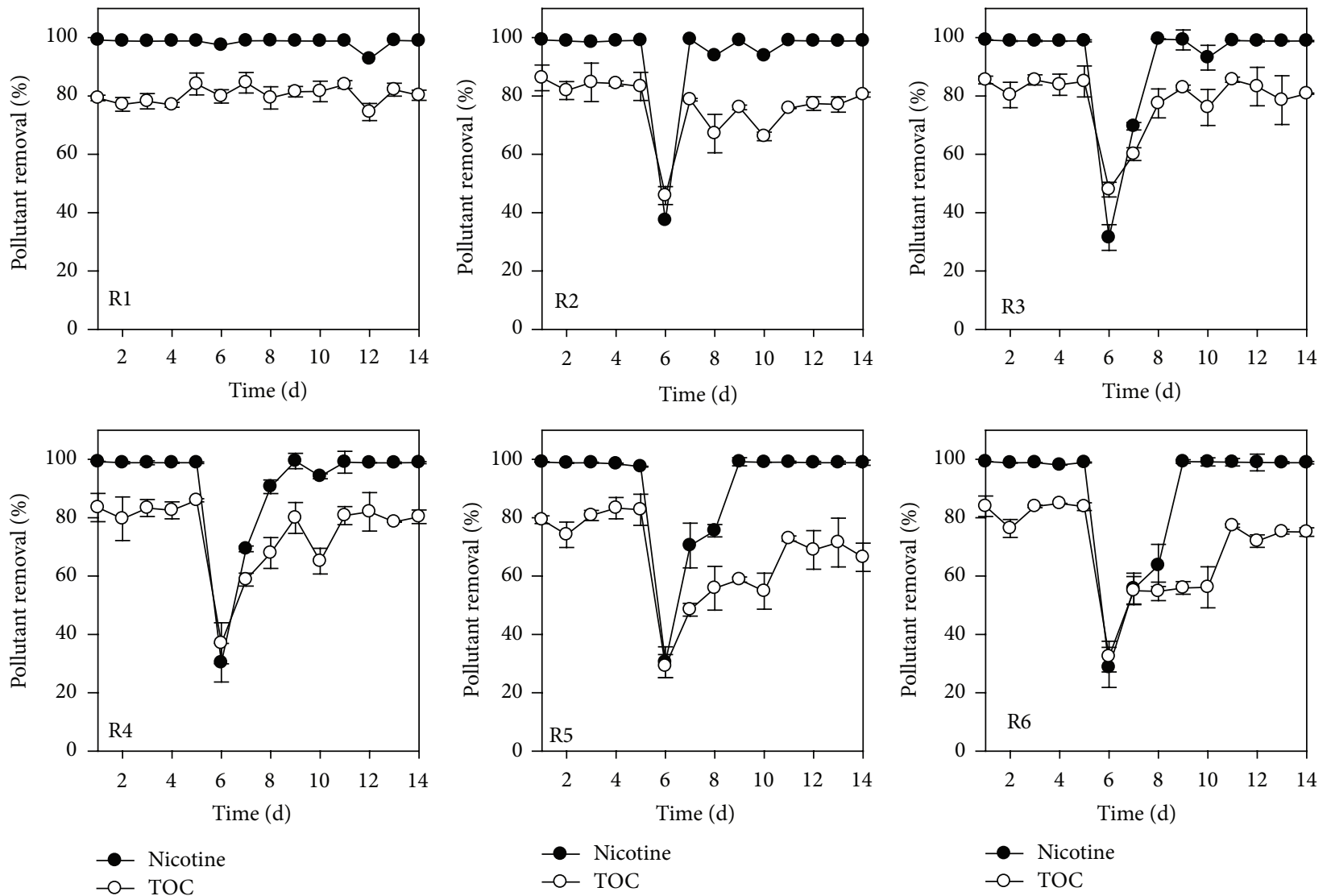

FIGURE 1: Effect of nicotine shock on pollutant removal in SBRs treating tobacco wastewater. Reactor R1 was the control without nicotine shock load; reactors R2 to R6 were with the nicotine shock load of 500, 1000, 1500, 2000, and 2500 mg/L, respectively.

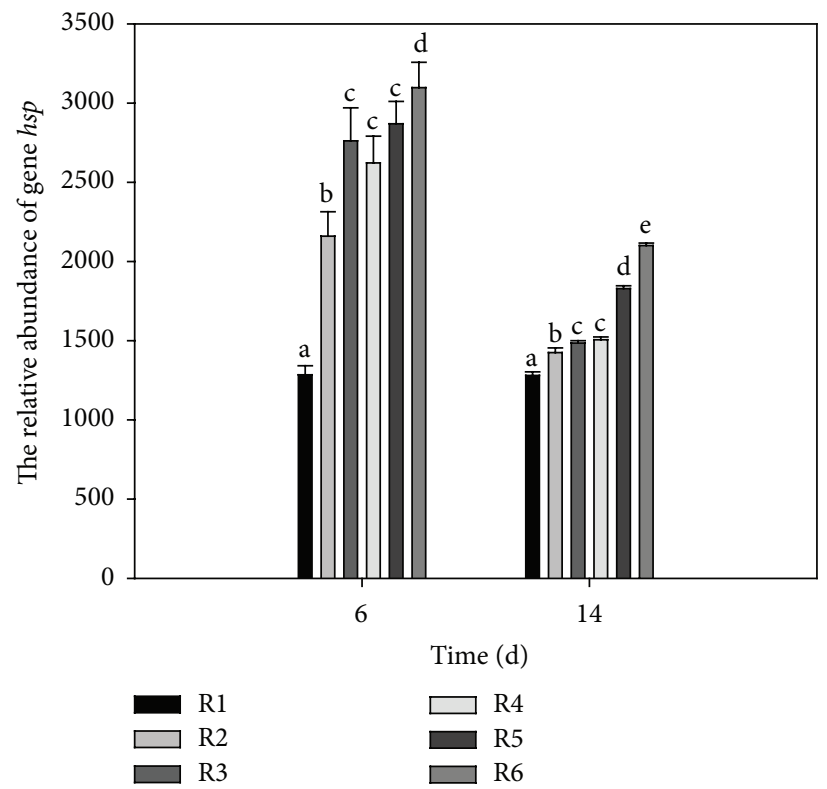

FIGURE 2: Changes of the activity of HSP hydroxylase in the reactors with different nicotine shock loads. Reactor R1 was the control without nicotine shock load; reactors R2 to R6 were with the nicotine shock load of 500, 1000, 1500, 2000, and 2500 mg/L, respectively. Different letters represent significant differences between reactors $(p<0.05)$. 


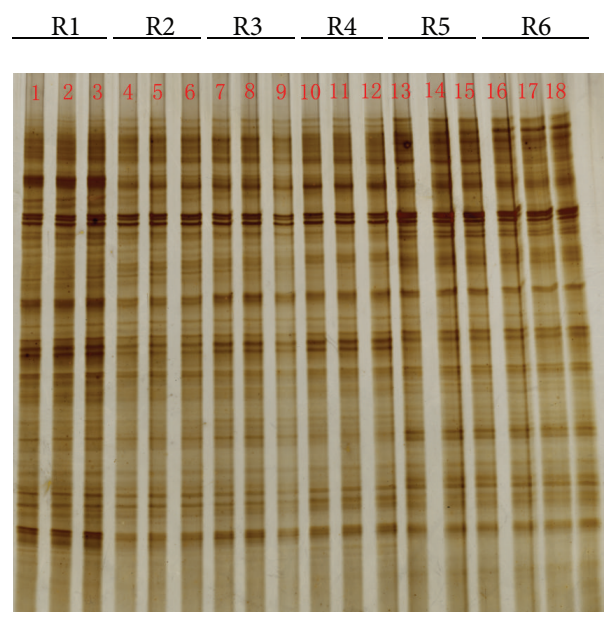

(a)

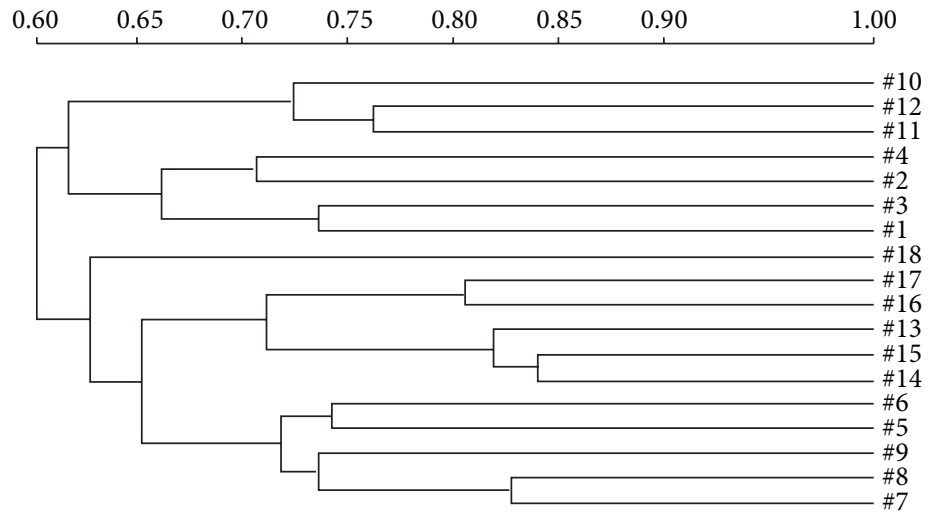

(b)

FIGURE 3: PCR-DGGE fingerprints and their clustering analysis of the reactors with different nicotine shock loads. (a) DGGE pattern of the reactors; (b) clustering analysis of the reactors.

of destroying the balance between oxidation and antioxidation in cells [24]. The change of ROS content is shown in Figure 4(a). Before nicotine shock loads, the contents of ROS in all reactors were almost the same and close to $20 \mathrm{U} / \mathrm{mg}$ prot. After nicotine shock, the content of ROS in the reactors with more than $1000 \mathrm{mg} / \mathrm{L}$ nicotine loads went up sharply. After recovery for 8 cycles, the ROS value in most of the reactors (R2-R4) returned to the initial level. However, the ROS value in R5-R6 was still higher than the initial level.

Meanwhile, we detected the content of MDA, which is the product of membrane lipid peroxidation [25]. The change of MDA content is shown in Figure 4(b). Before nicotine shock loads, the content of MDA in all reactors was almost the same and close to $4 \mathrm{~mol} / \mathrm{mg}$ prot. A dramatic increase in MDA content was observed in the reactors with 1000 , 1500,2000 , and $2500 \mathrm{mg} / \mathrm{L}$ nicotine shock loads, reaching levels that were 1.2-, 1.4-, 2-, and 2.4-fold higher than the one observed in the control reactor R1, respectively. The results were in accordance with the content of ROS. These results indicated that oxidative stress was induced when nicotine shock higher was than $1000 \mathrm{mg} / \mathrm{L}$.

After the influent concentrations of nicotine returned to $250 \mathrm{mg} / \mathrm{L}$ and performed for 8 cycles, the content of MDA decreased below the control level in 14th d. However, the ROS value in R5-R6 was still higher than the initial level. ROS could produce a variety of oxidative stress, including lipid peroxidation, DNA damage, and inactivation of many enzymes [11, 26]. Though lipid peroxidation was recovered, other kinds of oxidative stress could put the native microorganisms into suffering longer, which is possibly one of the main reasons for nonrecovery of TOC removal. Thus, compared to other biomarkers for oxidative damage like MDA, the content of ROS is one of the direct and convincing biomarkers.

SOD and CAT are two main kinds of antioxidant enzymes in organisms, which could eliminate a certain amount of ROS quickly. The change in SOD and CAT activities of all reactors was evaluated and presented in Figures 4(c) and 4(d). The SOD activity in reactors R2, R3, and R4 with nicotine concentration of 500,1000 , and $1500 \mathrm{mg} / \mathrm{L}$ almost had no change after shock loading, while the SOD activity in reactors R5 and R6 with 2000 and $2500 \mathrm{mg} / \mathrm{L}$ reached up to 45.6 and $49.3 \mathrm{~mol} / \mathrm{mg}$ prot, respectively. Meanwhile, after nicotine shock loads, the activities of CAT in R2, R3, R4, R5, and R6 were significantly higher than those on day 4 . This suggested that both SOD and CAT played important roles in eliminating ROS induced by nicotine. Compared to SOD, CAT played a longer role in eliminating ROS. In the complicated system, we do not recommend using SOD and CAT as biomarkers.

\section{Conclusions}

The bioaugmented activated sludge system with strain HF-1 has a good performance to deal with nicotine shock. It took $2,3,4,4$, and $4 \mathrm{~d}$ to recover under 500, 1000, 1500, 2000, and $2500 \mathrm{mg} / \mathrm{L}$ of nicotine shock, respectively. The nicotine shock would not damage the ability of nicotine degradation of strain HF-1. On the contrary, it would stimulate the activity of HSP hydroxylase, which is key enzyme for nicotine degradation. Though a dramatic increase of ROS, MDA, SOD, and CAT suggested that nicotine shock induced oxidative stress on microorganisms in activated sludge, their decrease to control level demonstrated that activated sludge could resist $500-1500 \mathrm{mg} / \mathrm{L}$ of transient nicotine shock with protection from strain HF-1. However, under 2000-2500 mg/L nicotine shock, native microorganisms would be damaged by extremely high ROS in systems. Due to diversity oxidative stress on native microorganisms, MDA, SOD, and CAT were not suitable for biomarker under transient nicotine shock. Comparatively, as the direct reflection on oxidative stress, ROS could be selected as biomarker under transient nicotine shock. 


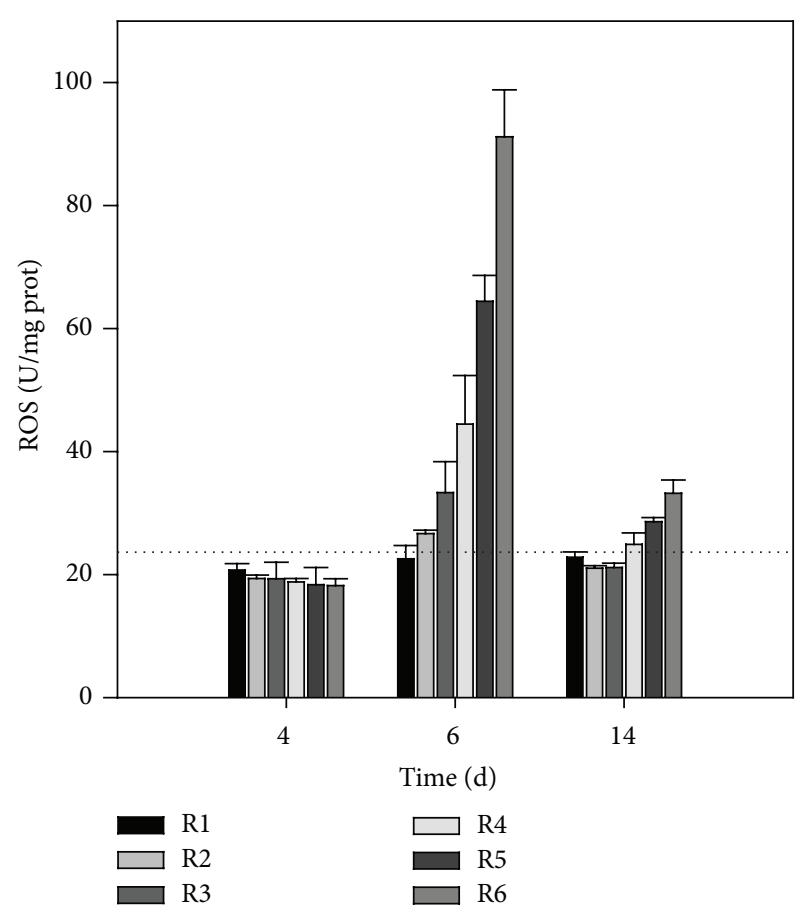

(a)

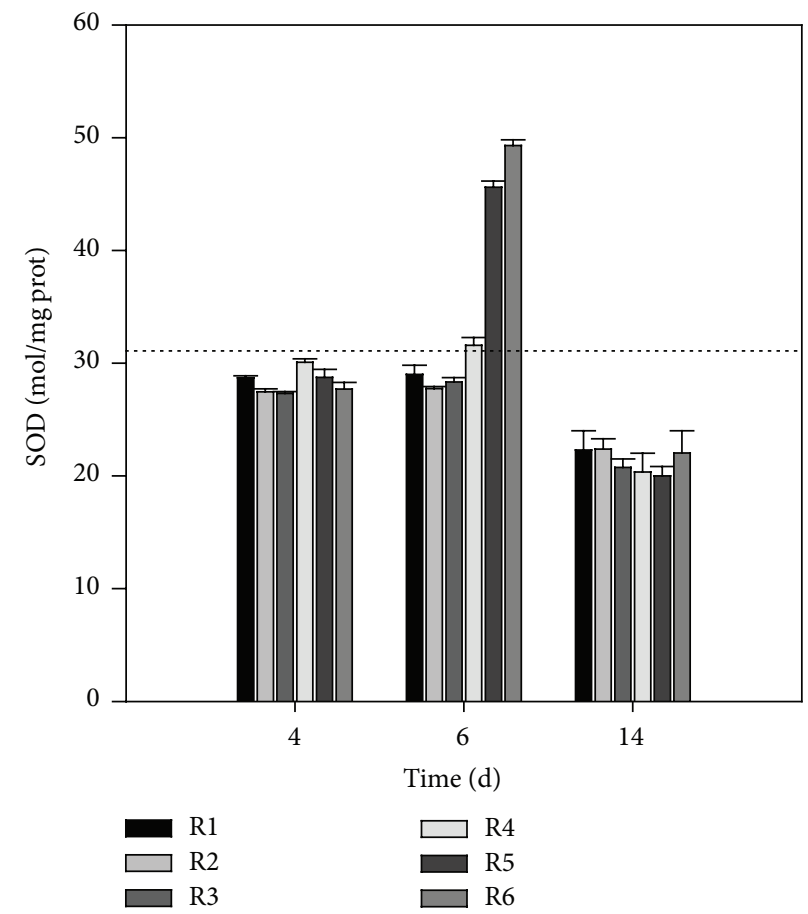

(c)

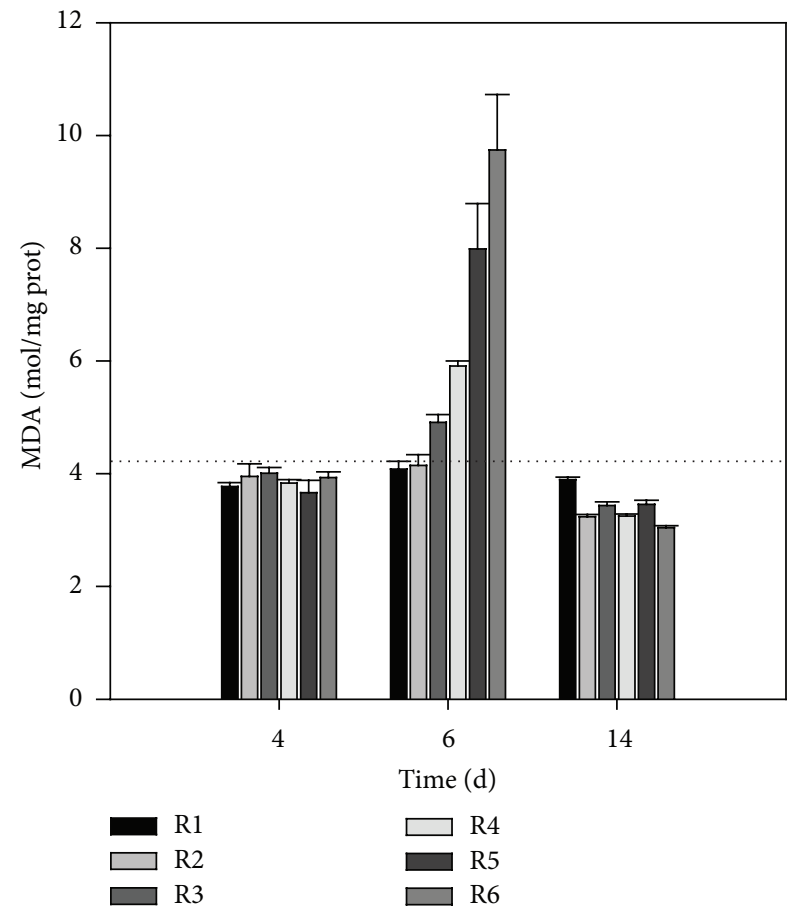

(b)

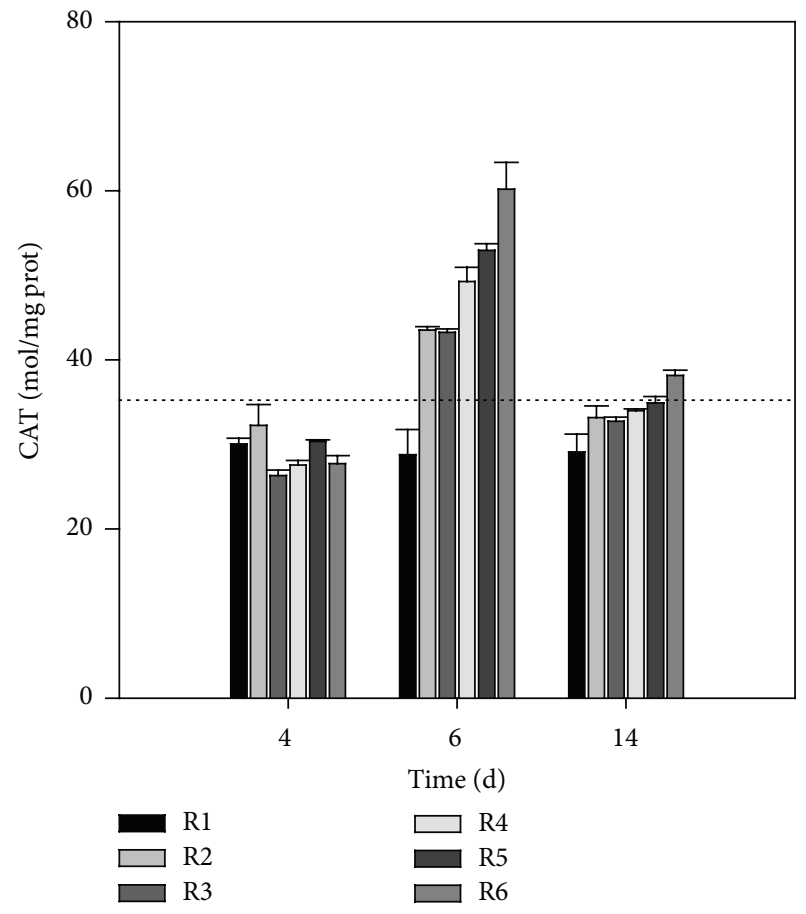

(d)

FIGURE 4: The oxidative stress in the reactors with different nicotine shock loads. Reactor R1 was the control without nicotine shock load; reactors R2 to R6 were with the nicotine shock load of 500, 1000, 1500, 2000, and $2500 \mathrm{mg} / \mathrm{L}$, respectively. (a) ROS; (b) MDA; (c) SOD; and (d) CAT. 
Abbreviations

$\begin{array}{ll}\text { BOD: } & \text { Biochemical oxygen demand } \\ \text { CAT: } & \text { Catalase } \\ \text { COD: } & \text { Chemical oxygen demand } \\ \text { DO: } & \text { Dissolved oxygen } \\ \text { HPLC: } & \begin{array}{l}\text { High performance liquid } \\ \text { chromatography }\end{array} \\ & \text { Hydraulic retention time } \\ \text { HRT: } & \text { 6-Hydroxy-3-succinoylpyridine } \\ \text { HSP: } & \text { Malondialdehyde } \\ \text { MDA: } & \text { denaturing gradient gel } \\ \text { PCR-DGGE: } & \text { Polymerase chain reaction and } \\ & \text { electrophoresis } \\ \text { ROS: } & \text { Reactive oxygen species } \\ \text { SBR: } & \text { Sequencing batch reactor } \\ \text { SOD: } & \text { Superoxide dismutase } \\ \text { TOC: } & \text { Total organic carbon. }\end{array}$

\section{Competing Interests}

The authors declare that there is no conflict of interests regarding the publication of this paper.

\section{Acknowledgments}

This work was supported by the Natural Science Foundation of Zhejiang Province (LY15C010001) and the National Natural Science Foundation of China (31570490).

\section{References}

[1] M. Wang, G. Yang, H. Min, Z. Lv, and X. Jia, "Bioaugmentation with the nicotine-degrading bacterium Pseudomonas sp. HF1 in a sequencing batch reactor treating tobacco wastewater: degradation study and analysis of its mechanisms," Water Research, vol. 43, no. 17, pp. 4187-4196, 2009.

[2] W. Zhong, C. Zhu, M. Shu et al., "Degradation of nicotine in tobacco waste extract by newly isolated Pseudomonas sp. ZUTSKD," Bioresource Technology, vol. 101, no. 18, pp. 69356941, 2010.

[3] I. J. Buerge, M. Kahle, H.-R. Buser, M. D. Müller, and T. Poiger, "Nicotine derivatives in wastewater and surface waters: application as chemical markers for domestic wastewater," Environmental Science \& Technology, vol. 42, no. 17, pp. 63546360, 2008.

[4] Y. Tega, S.-I. Akanuma, Y. Kubo, T. Terasaki, and K.-I. Hosoya, "Blood-to-brain influx transport of nicotine at the rat bloodbrain barrier: involvement of a pyrilamine-sensitive organic cation transport process," Neurochemistry International, vol. 62, no. 2, pp. 173-181, 2013.

[5] S. A. Grando, "Connections of nicotine to cancer," Nature Reviews Cancer, vol. 14, no. 6, pp. 419-429, 2014.

[6] C. N. Albers, L. Feld, L. Ellegaard-Jensen, and J. Aamand, "Degradation of trace concentrations of the persistent groundwater pollutant 2,6-dichlorobenzamide (BAM) in bioaugmented rapid sand filters," Water Research, vol. 83, pp. 61-70, 2015.

[7] M. Herrero and D. C. Stuckey, "Bioaugmentation and its application in wastewater treatment: a review," Chemosphere, vol. 140, pp. 119-128, 2015.
[8] J. Qiu, Y. Wei, Y. Ma, R. Wen, Y. Wen, and W. Liu, "A novel (S)6-hydroxynicotine oxidase gene from Shinella sp. Strain HZN7," Applied and Environmental Microbiology, vol. 80, no. 18, pp. 5552-5560, 2014.

[9] S. Xue, J. E. Schlosburg, and K. D. Janda, "A new strategy for smoking cessation: characterization of a bacterial enzyme for the degradation of nicotine," Journal of the American Chemical Society, vol. 137, no. 32, pp. 10136-10139, 2015.

[10] J.-H. Wang, H.-Z. He, M.-Z. Wang et al., "Bioaugmentation of activated sludge with Acinetobacter sp. TW enhances nicotine degradation in a synthetic tobacco wastewater treatment system," Bioresource Technology, vol. 142, pp. 445-453, 2013.

[11] T. Shao, G. Yang, M. Wang, Z. Lu, H. Min, and L. Zhao, "Reduction of oxidative stress by bioaugmented strain Pseudomonas sp. HF-1 and selection of potential biomarkers in sequencing batch reactor treating tobacco wastewater," Ecotoxicology, vol. 19, no. 6, pp. 1117-1123, 2010.

[12] H. Li, L. Tan, S. Ning, and M. He, "Reactor performance and microbial community dynamics during aerobic degradation and detoxification of Acid Red B with activated sludge bioaugmented by a yeast Candida tropicalis TL-F1 in MBR," International Biodeterioration and Biodegradation, vol. 104, pp. 149-156, 2015.

[13] K. Zhang, X. Zheng, D.-S. Shen et al., "Evidence for existence of quorum sensing in a bioaugmented system by acylated homoserine lactone-dependent quorum quenching," Environmental Science and Pollution Research, vol. 22, no. 8, pp. 60506056, 2015.

[14] H. He, M. Wang, H. Feng, X. Zheng, and D. Shen, "Application of antioxidant indicators to select nicotine-degrading bacterium for bioaugmented treatment of tobacco wastewater," Journal of the Chemical Society of Pakistan, vol. 35, no. 4, pp. 1202-1207, 2013.

[15] J. Zhang, R.-B. Guo, Y.-L. Qiu et al., "Bioaugmentation with an acetate-type fermentation bacterium Acetobacteroides hydrogenigenes improves methane production from corn straw," Bioresource Technology, vol. 179, pp. 306-313, 2015.

[16] K. J. Livak and T. D. Schmittgen, "Analysis of relative gene expression data using real-time quantitative PCR and the $2^{-\triangle \Delta C T}$ method," Methods, vol. 25, no. 4, pp. 402-408, 2001.

[17] S. L. Edenborn and A. J. Sexstone, "DGGE fingerprinting of culturable soil bacterial communities complements cultureindependent analyses," Soil Biology and Biochemistry, vol. 39, no. 7, pp. 1570-1579, 2007.

[18] A.-J. Li, S.-F. Yang, X.-Y. Li, and J.-D. Gu, "Microbial population dynamics during aerobic sludge granulation at different organic loading rates," Water Research, vol. 42, no. 13, pp. 3552-3560, 2008.

[19] N. J. Kruger, “The Bradford method for protein quantitation," in The Protein Protocols Handbook, pp. 17-24, 2009.

[20] H. Tang, S. Wang, L. Ma et al., "A novel gene, encoding 6hydroxy-3-succinoylpyridine hydroxylase, involved in nicotine degradation by Pseudomonas putida strain S16," Applied and Environmental Microbiology, vol. 74, no. 5, pp. 1567-1574, 2008.

[21] H. Tang, Y. Yao, D. Zhang et al., "A novel NADH-dependent and FAD-containing hydroxylase is crucial for nicotine degradation by Pseudomonas putida," The Journal of Biological Chemistry, vol. 286, no. 45, pp. 39179-39187, 2011.

[22] H. Yu, R. P. Hausinger, H.-Z. Tang, and P. Xu, "Mechanism of the 6-hydroxy-3-succinoyl-pyridine 3-monooxygenase flavoprotein from Pseudomonas putida S16," Journal of Biological Chemistry, vol. 289, no. 42, pp. 29158-29170, 2014. 
[23] Y.-F. Wang, F.-Q. Zhang, and J.-D. Gu, "Improvement of DGGE analysis by modifications of PCR protocols for analysis of microbial community members with low abundance," Applied Microbiology and Biotechnology, vol. 98, no. 12, pp. 5655-5663, 2014.

[24] X. Zhao and K. Drlica, "Reactive oxygen species and the bacterial response to lethal stress," Current Opinion in Microbiology, vol. 21, pp. 1-6, 2014.

[25] L. Ernster and P. Hochstein, "Membrane lipid peroxidation: cellular mechanisms and toxicological implications," In Vitro Toxicity Indicators, vol. 1, 2013.

[26] Nagarajappa, A. Ganguly, and U. Goswami, "DNA damage in male gonad cells of Green mussel (Perna viridis) upon exposure to tobacco products," Ecotoxicology, vol. 15, no. 4, pp. 365-369, 2006. 

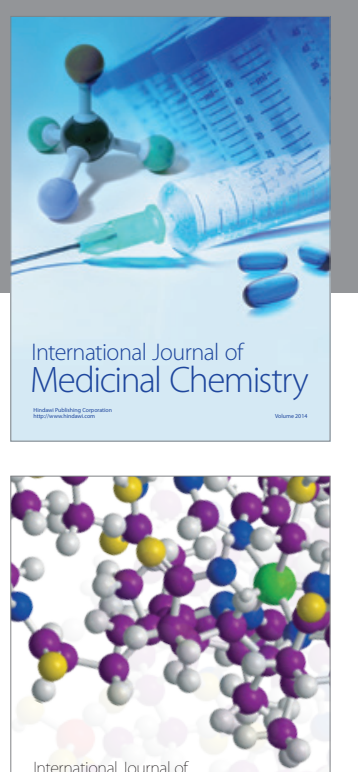

Carbohydrate Chemistry

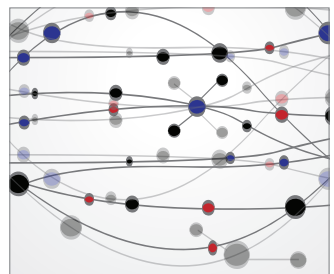

The Scientific World Journal
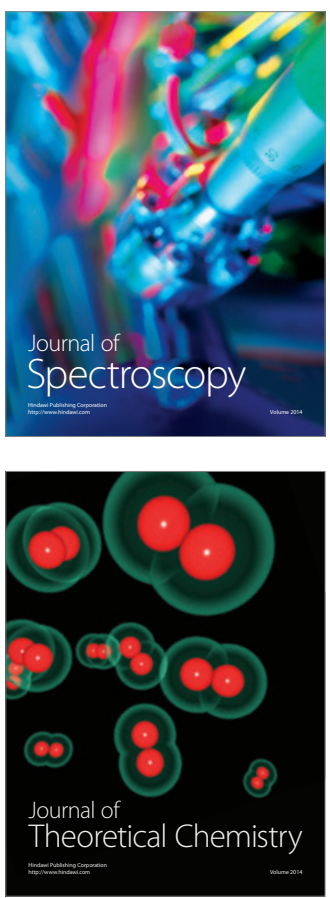
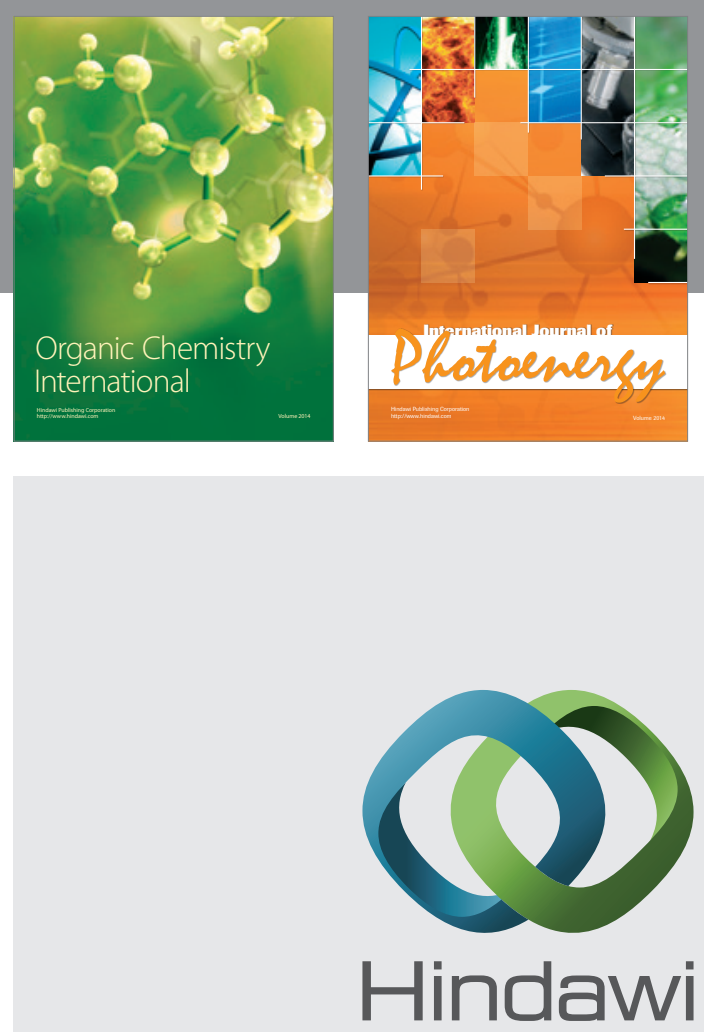

Submit your manuscripts at

http://www.hindawi.com

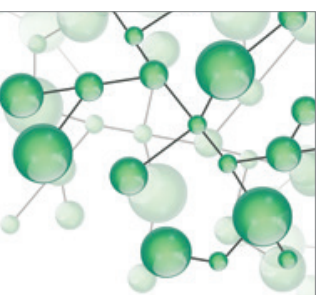

International Journal of

Inorganic Chemistry

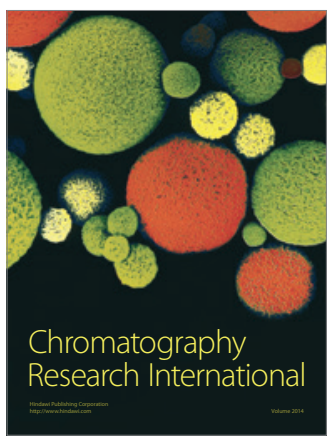

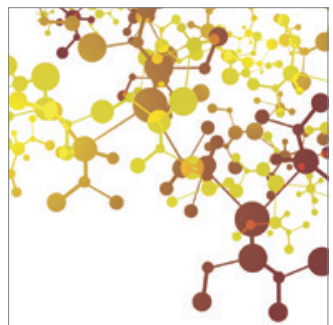

Applied Chemistry
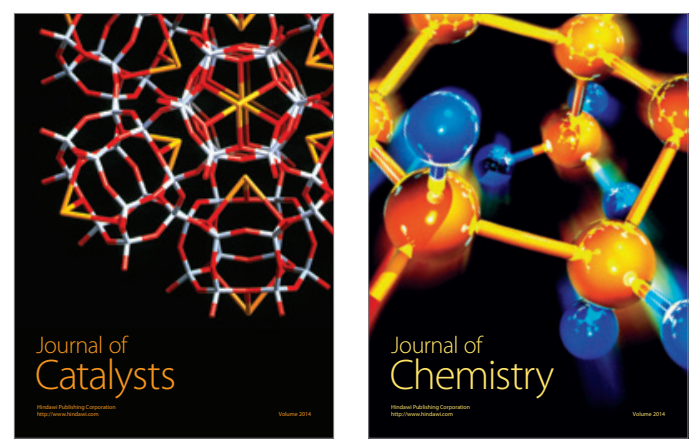
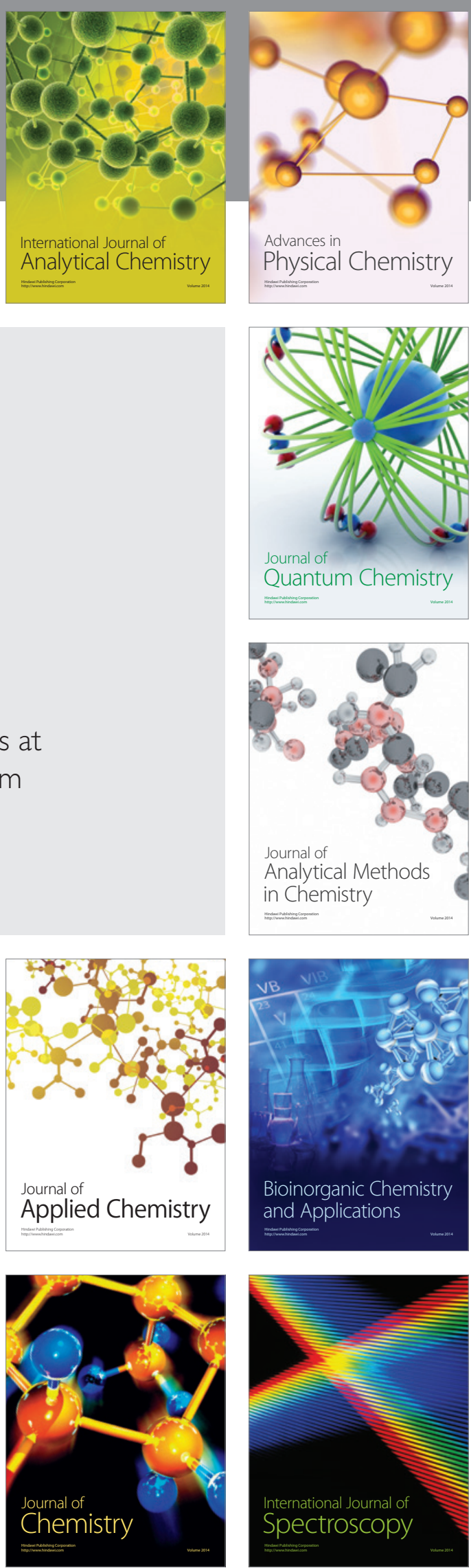